\title{
PENGARUH SUBSTITUSI SILASE ISI RUMEN SAPI PADA PAKAN BASAL RUMPUT DAN KONSENTRAT TERHADAP KINERJA SAPI POTONG
}

\section{EFFECT OF RUMEN CONTENT SILAGE SUBSTITUTION TO KING GRASS BASAL FEED ON CROSSBREED CATTLE PERFORMANCE}

\author{
Engkus Ainul Yakin ${ }^{1 *}$, Nono Ngadiyono ${ }^{2}$, dan Ristianto Utomo ${ }^{2}$ \\ ${ }^{1}$ Fakultas Pertanian, Universitas Veteran Bangun Nusantara Sukoharjo \\ ${ }^{2}$ Fakultas Peternakan, Universitas Gadjah Mada, Jl. Fauna No. 3, Bulaksumur, Yogyakarta, 55281
}

\begin{abstract}
INTISARI
Penelitian bertujuan untuk mengetahui pengaruh pemberian silase isi rumen sapi sebagai pakan pengganti rumput terhadap kinerja sapi potong. Sapi persilangan Simmental-Peranakan Ongole (SimPO) jantan sebanyak 12 ekor, umur 1,5-2 tahun, digunakan dalam penelitian ini. Penelitian dilakukan selama 8 minggu (2 bulan) dengan pemberian pakan sebesar 3\% dari bobot badan berdasarkan bahan kering dan air minum diberikan secara ad libitum. Penelitian ini menggunakan Rancangan Acak Lengkap pola searah dilanjutkan Duncan's New Multiple Range Test (DMRT). Perlakuan yang diberikan yaitu mengganti sebagian rumput dengan silase isi rumen sapi, yaitu $\mathrm{P} 0=$ pemberian pakan $100 \%$ rumput , $\mathrm{P} 1=$ pemberian pakan $25 \%$ silase isi rumen sapi dan $75 \%$ rumput, dan $\mathrm{P} 2=$ pemberian pakan $50 \%$ silase isi rumen sapi dan 50\% rumput. Imbangan pakan antara rumput dan konsentrat adalah 20\% : 80\%. Variabel yang diamati adalah konsumsi pakan, pertambahan bobot badan harian (PBBH), dan konversi pakan. Hasil penelitian menunjukkan bahwa perlakuan tidak berpengaruh nyata terhadap konsumsi bahan kering (BK) (13,23 $\pm 0,63$ $\mathrm{kg} /$ ekor/hari), konsumsi bahan organik (BO) $(10,41 \pm 0,50 \mathrm{~kg} /$ ekor/hari), konsumsi total digestible nutrients (TDN) $(7,38 \pm 0,37 \mathrm{~kg} / \mathrm{ekor} /$ hari $), \mathrm{PBBH}(0,95 \pm 0,04 \mathrm{~kg} / \mathrm{ekor} / \mathrm{hari})$, dan konversi pakan $(7,38 \pm 0,37)$. Perlakuan berpengaruh $(\mathrm{P}<0,05)$ terhadap konsumsi protein kasar $(\mathrm{PK})(\mathrm{P} 0=0,94 \pm 0,03, \mathrm{P} 1=1,00 \pm 0,06$ dan $\mathrm{P} 2=0,98 \pm 0,01)$, dan serat kasar $(\mathrm{SK})(\mathrm{P} 0=3,26 \pm 0,10, \mathrm{P} 1=3,44 \pm 0,22$ dan $\mathrm{P} 2=3,27 \pm 0,04)$. Disimpulkan bahwa penggantian sebagian rumput dengan silase isi rumen sampai $50 \%$ tidak mempengaruhi kinerja sapi potong.
\end{abstract}

(Kata kunci: Isi rumen sapi, Sapi potong, Silase)

\section{ABSTRACT}

The research aimed to investigate the effect of silage of cattle rumen content as grass subtitution on the performance of crossbreed beef cattle. Twelve Simmental-Ongole crossbreed (SimPO) cattles aged of 1.5-2 years were adopted in the experiments for 8 weeks (2 months). Beef cattles were fed of $3 \%$ of body weight based on dry matter. Water was provided ad libitum. Data were analyzed using one way complete randomized design continued by DMRT. The treatment consisted of $T 0=$ giving $100 \%$ grass , $T 1=$ giving $25 \%$ cattle rumen content silage and $75 \%$ grass, and $T 2=$ giving 50\% cattle rumen content silage and 50\% grass. The ratio of grass to concentrate was $20 \%: 80 \%$. Variables measured were feed consumption, average daily gain and feed conversion. The result showed that the treatment did not significantly influence dry matter (DM) consumption (13.23 $\pm 0.63 \mathrm{~kg} / \mathrm{head} /$ day), organic matter (OM) consumption $(10.41 \pm 0.50 \mathrm{~kg} / \mathrm{head} /$ day), total digestible nutriens (TDN) consumption ( $7.38 \pm 0.37 \mathrm{~kg} / \mathrm{head} /$ day), and also average daily gain $(0.95 \pm 0.04 \mathrm{~kg} / \mathrm{head} /$ day), and feed conversion $(7.38 \pm 0.77)$, but significanly affected $(P<0.05)$ crude protein $(C P)$ consumption $(P 0=0.94 \pm 0.03, P 1=1.00 \pm 0.06$ and $P 2=0.98 \pm 0.01)$ and crude fiber $(C F)$ consumption $(P 0=3.26 \pm 0.10, P 1=3.44 \pm 0.22$ and $P 2=3.27 \pm 0.04)$. It can be concluded that the substitution of the grass by rumen content silage up to $50 \%$ had no effect on the SimPO performance.

(Key word: Cattle rument content, Beef cattle, Silage)

\section{Pendahuluan}

Dewasa ini, sapi potong di negara majuternak sudah terspesialisasi ke arah satu produksi, salah satunya daging (Parakkasi, 1999). Untuk dapat mencapai produksi daging yang maksimal

\footnotetext{
* Korespondensi (corresponding author):

Telp. +62 81329104282

E-mail: gazza_eay@yahoo.com
}

pakan memegang peranan yang sangat penting dalam pemenuhan kebutuhan untuk pertumbuhan. Pertumbuhan ternak sapi dipengaruhi oleh beberapa faktor, diantaranya adalah bangsa, jenis kelamin serta kualitas dan kuantitas pakan. Tillman et al. (1998) berpendapat bahwa kecepatan pertumbuhan ternak sangat dipengaruhi oleh jumlah konsumsi pakan. Kekurangan pakan merupakan kendala besar dalam proses pertumbuhan. Ternak membutuhkan 
nutrisi pakan yang memenuhi syarat yaitu protein, karbohidrat, lemak, mineral, vitamin, dan air. Nutrisi dalam pakan dipakai untuk hidup pokok, jika kebutuhan pokok masih ada kelebihan, maka digunakan untuk pertumbuhan atau disimpan dalam bentuk lemak dan daging.

Iklim di Indonesia yang mempunyai dua musim yaitu musim penghujan dan musim kemarau, sangat berpengaruh pada penyediaan pakan. Pada musim hujan pakan berupa hijauan dapat didapatkan dengan mudah, akan tetapi pada musim kemarau pakan berupa hijauan menjadi langka dan sulit didapatkan, dan kalaupun ada harganya mahal. Apabila peternak terpaksa membeli hijauan pada musim kemarau tentunya hal ini akan berimbas pada turunnya pendapatan dikarenakan harus membeli pakan rumput tersebut.

Untuk mensiasati hal tersebut maka salah satu cara yang dilakukan adalah dengan mengawetkan hijauan yang kemudian bisa diberikan pada musim kemarau, akan tetapi bila jumlah hijauan yang tersedia terbatas maka perlu dicari bahan pakan lain yang kandungan nutrisinya tidak berbeda jauh dengan rumput. Rumput memiliki kandungan nutrisi yang rendah sehingga perlu disubstitusi bahan pakan lain untuk meningkatkan nilai nutrisi pakan rumput.

Salah satu limbah industri rumah potong hewan yang dapat digunakan sebagai pakan ternak yaitu isi rumen sapi. Isi rumen dari pemotongan sapi biasanya hanya dibuang, padahal per ekor sapi dapat menghasilkan isi rumen segar $24,5 \mathrm{~kg}$ atau 3,8 $\mathrm{kg}$ BK, karena mengandung BK 15,5\% (Witherow dan Lammers, 1976 cit. Utomo et al., 2007) sehingga dari jumlah pemotongan sapi di Indonesia tahun 2008 didapat isi rumen sapi segar sebanyak 46.525.500 kg. Rumah potong hewan Giwangan yang ada di kota Yogyakarta dalam sehari memotong rata-rata 20 ekor sapi, sehingga isi rumen sapi yang dihasilkan sekitar $490 \mathrm{~kg}$ /hari. Isi rumen ini masih dapat digunakan sebagai pakan ternak sapi bila diolah lagi dengan baik dan benar sehingga peternak tidak akan bingung lagi mencari pakan hijauan pada musim kemarau.

Penggunaan isi rumen sebagai salah satu bahan pakan alternatif untuk memenuhi kebutuhan pakan sangat membantu penyediaan pakan, kelestarian lingkungan, dan mendukung program pembangunan khususnya di perkotaan.

Penggunaan isi rumen sapi dari rumah potong hewan sebagai pakan ternak potong dilaporkan oleh Messermith (1973) yang menggunakan isi rumen sebagai bahan penyusun ransum sapi potong sampai 15\% dapat menghasilkan PBBH, konsumsi pakan, efisiensi dan konversi pakan yang tidak berbeda nyata dengan kontrol. Pembuatan silase isi rumen pernah dilakukan dengan penambahan onggok kering namun dengan penambahan dedak halus belum pernah dilakukan.

Tujuan penelitian ini untuk mengetahui pengaruh substitusi silase isi rumen sapi pada pakan basal terhadap kinerja sapi potong jantan yang digemukkan di suatu usaha penggemukan, yang meliputi konsumsi pakan, PBBH, dan konversi pakan. Manfaat penelitian yaitu mempunyai kaitan erat dengan penggunaan bahan pakan hasil limbah industri rumah potong hewan (RPH) untuk usaha sapi potong dengan tujuan mendapatkan hasil yang menguntungkan dan efisien.

\section{Materi dan Metode Penelitian}

Penelitian ini dilaksanakan pada bulan Agustus sampai November 2011. Tempat penelitian di RPH Giwangan Yogyakarta, dan di usaha penggemukan sapi potong Dusun Jarum, Desa Kayuloko, Kecamatan Sidoharjo, Kabupaten Wonogiri. Uji kandungan nutrisi pakan dilakukan di Laboratorium Biokimia Fakultas Peternakan, Universitas Gadjah Mada, Yogyakarta.

Isi rumen sapi yang digunakan dalam penelitian ini diperoleh dari rumah potong hewan Giwangan Yogyakarta. Isi rumen sapi dipilih yang berwarna hijau karena mengindikasikan bahwa ternak sapi mengkonsumsi pakan hijauan.

Sebelum dilakukan pembuatan silase isi rumen sapi, terlebih dahulu dilakukan analisis komposisi kimia bahan dasar pembuatan silase, yaitu isi rumen sapi, dedak halus, dan molases, dengan analisis proksimat. Pembuatan silase isi rumen dilakukan dengan komposisi isi rumen $64,60 \%$, dedak halus $35,40 \%$ sehingga didapatkan BK campuran bahan silase $35 \%$, ditambahkan molases $8 \%$ dari bahan baku silase dan diinokulasi dengan bakteri Lactobacillus plantarum $0,1 \%$ dari bahan baku silase. Bahan silase selanjutnya dimasukkan ke dalam kantong plastik polyethylene hitam kedap udara (Utomo et al., 2007). Lama fermentasi selama 21 hari. Silase yang telah jadi kemudian dianalisis proksimat untuk mengetahui komposisi kimia setelah menjadi silase.

Sapi dipelihara dalam kandang individu, sebanyak 12 petak, dengan ukuran $100 \times 150 \mathrm{~cm}^{2}$ per petak. Alas kandang berupa cor semen yang dialasi karet agar sapi tidak terpeleset. Dinding kandang dari batu bata dan atap menggunakan genting. Peralatan yang digunakan berupa seperangkat alat kandang, vacum cleaner, plastik polyethylene hitam, tali rapia, timbangan ternak merk Ruddweight kapasitas $1.250 \mathrm{~kg}$ dengan kepekaan $1 \mathrm{~kg}$ dan timbangan pakan merk Goat kapasitas $15 \mathrm{~kg}$ dengan kepekaan $50 \mathrm{~g}$ serta seperangkat alat laboratorium untuk analisis pakan. 
Bahan-bahan yang digunakan dalam penyusunan ransum penelitian adalah rumput gajah, silase isi rumen, dan konsentrat dengan merk nutrisi fit produksi PT. Global Nutrisi yang komposisi nutrisinya tersaji pada Tabel 1.

Penelitian ini berlangsung selama 12 minggu dimana 3 minggu awal digunakan untuk pembuatan silase isi rumen, 1 minggu digunakan untuk adaptasi pakan, dan 8 minggu adalah pelaksanaan penelitian pemberian pakan silase isi rumen. Pakan konsentrat diberikan dua kali sehari yaitu pada pukul 08.00 dan pukul $16.00 \mathrm{WIB}$, sedangkan pakan silase isi rumen sapi diberikan sekali pada pukul 08.00 pagi sebelum konsentrat, sedangkan pakan rumput diberikan pada siang hari pada pukul 12.00 sampai dengan 13.00 WIB. Air minum diberikan secara ad libitum selama penelitian berlangsung.

Sapi yang digunakan dalam penelitian ini sebanyak 12 ekor sapi simPO jantan dengan umur 1,5-2 tahun. Bobot sapi 350-400 kg. Sapi dibagi dalam 3 macam perlakuan pemberian pakan.

Pemberian pakan kontrol yaitu menggunakan imbangan hijauan : konsentrat $=20 \%: 80 \%$. Pola pemberian pakan dalam penelitian ini meliputi tiga macam perlakuan yaitu:

P0 : kontrol (tanpa penambahan silase isi rumen sapi).

P1 : silase isi rumen sapi $25 \%$ dan rumput $75 \%$.

$\mathrm{P} 2$ : silase isi rumen sapi $50 \%$ dan rumput $50 \%$.

Penimbangan ternak dilakukan setiap 1 minggu sekali untuk mengetahui rata-rata $\mathrm{PBBH}$ dalam 1 minggu dengan tujuan untuk menghitung jumlah pakan yang diberikan yaitu $3 \%$ BB. Penimbangan pakan dan sisa pakan setiap hari sekali selama penelitian berlangsung ( 8 minggu).

Data konsumsi pakan, PBBH dan konversi pakan dianalisis menggunakan desain penelitian Rancangan Acak Lengkap dengan analisis sidik ragam pola searah (oneway ANOVA). Apabila hasil uji signifikan, dilakukan uji lanjut dengan analisis uji jarak berganda Duncan's New Multiple Range Test (DMRT) (Christensen, 1996).

\section{Hasil dan Pembahasan}

\section{Konsumsi pakan}

Konsumsi pakan hasil penelitian ini yang meliputi konsumsi BK, PK, SK, BO, dan TDN tercantum dalam pada Tabel 2. Hasil analisis statistik menunjukkan bahwa semua variabel yang diamati berbeda tidak nyata, kecuali konsumsi PK dan SK dalam $\mathrm{g} / \mathrm{kg}$ bobot badan metabolik berbeda nyata $(\mathrm{P}<0,05)$.

Konsumsi bahan kering. Hasil analisis statistik konsumsi $\mathrm{BK}\left(\mathrm{g} / \mathrm{kg} \mathrm{BB}^{0,75}\right)$ dari ketiga perlakuan menunjukkan perbedaan tidak nyata berturut-turut yaitu $\mathrm{P} 0=136,44 \pm 0,94, \mathrm{P} 1=$
$137,64 \pm 2,45$, dan $\mathrm{P} 2=135,52 \pm 0,34 \mathrm{~g} / \mathrm{kg} \mathrm{BB}{ }^{0,75}$. Perbedaan yang tidak nyata ini terjadi karena hijauan rumput diganti dengan silase isi rumen sapi tetapi karena tingkat palatabilitas isi rumen sapi yang sama dengan hijauan sehingga hal ini tidak berpengaruh nyata terhadap konsumsi BK berdasar bobot badan metabolik.

Hasil rata-rata konsumsi BK penelitian yaitu $13,23 \pm 0,63 \mathrm{~kg} / \mathrm{ekor} / \mathrm{hari}$ sedangkan bobot badan rata-rata yaitu $445,44 \mathrm{~kg}$. Bila dilihat dari rata-rata bobot badan dan konsumsi BK penelitian terlihat bahwa konsumsi BK penelitian (kg/ekor/hari) lebih tinggi dari pendapat Kearl (1982) yang menyebutkan bahwa sapi dengan bobot badan $450 \mathrm{~kg}$ dengan PBBH $1 \mathrm{~kg}$, kebutuhan BK adalah 10,2 $\mathrm{kg} / \mathrm{ekor} / \mathrm{hari}$. Kearl (1982) menyatakan bahwa konsumsi pakan antara lain dipengaruhi oleh bobot hidup ternak. Arora (1989) menyatakan bahwa konsumsi BK pakan dipengaruhi oleh bobot badan, temperatur lingkungan dan karakteristik pakan yang meliputi kecernaan, palatabilitas, dan keseimbangan nutrisi dalam ransum.

Konsumsi BK (kg/ekor/hari) tinggi dikarenakan perbandingan pakan antara hijauan dan konsentrat yaitu 20:80\%. Pengaruh dari penggunaan pakan konsentrat yang mencapai $80 \%$ dari total pakan mengakibatkan tercukupinya kebutuhan BK karena konsentrat adalah bahan pakan yang mudah dicerna, sehingga laju pakan dalam saluran pencernaan lebih cepat, dan kosongnya saluran pencernaan ini memungkinkan sapi mengambil pakan lagi. Pakan konsentrat yang tinggi mengakibatkan tinggi konsumsi pakan BK karena laju pakan di dalam saluran pencernaan menjadi lebih cepat. Ini sesuai dengan pendapat Tillman et al. (1998) yang menyatakan bahwa konsentrat merupakan bahan pakan ternak yang mudah dicerna sehingga laju aliran pakan dalam saluran pencernaan lebih cepat dan memungkinkan ternak untuk menambah konsumsi pakan.

Konsumsi BK pada sapi, seperti halnya ternak ruminansia lainnya, banyak dipengaruhi oleh laju pencernaan bahan pakan dalam saluran pencernaan, laju pengeluaran sisa pakan yang dikonsumsi, dan tingkat pemenuhan nutrisi oleh bahan pakan yang dikonsumsi (Tillman et al., 1998). Menurut Parakkasi (1999), tinggi rendahnya konsumsi pakan pada ternak ruminansia dipengaruhi oleh bangsa ternak, faktor lingkungan, kondisi ternak serta faktor pakan. Utomo (2001) menyatakan bahwa banyak sedikitnya konsumsi nutrisi tergantung pada jumlah BK pakan yang dikonsumsi ternak dan kandungan nutrisi dalam pakan yang diberikan.

Menurut Van Soest (1994), konsumsi pakan merupakan banyaknya pakan yang dapat dimakan pada periode waktu tertentu yang merupakan faktor 
Tabel 1. Komposisi nutrisi pakan (\% BK) (nutrient compotition of feed (\% DM))

\begin{tabular}{lccc}
\hline \hline \multicolumn{1}{c}{ Nutrisi (nutrient) } & $\begin{array}{c}\text { Rumput gajah } \\
\text { (Pennisetum purpureum) }\end{array}$ & $\begin{array}{c}\text { Silase isi rumen (silage of } \\
\text { rumen content) }\end{array}$ & $\begin{array}{c}\text { Konsentrat } \\
\text { (concentrate) }\end{array}$ \\
\hline Bahan kering (dry matter) & 21,25 & 28,90 & 84,21 \\
Protein kasar (crude protein) & 8,81 & 12,73 & 4,41 \\
Serat kasar (crude fiber) & 22,60 & 27,16 & 25,53 \\
Bahan organik (organic matter) & 85,47 & 84,81 & 77,06 \\
Total digestible nutrient (TDN) & 60,44 & 65,11 & 53,55 \\
Abu (ash) & 14,53 & 15,19 & 22,94 \\
\hline
\end{tabular}

Tabel 2. Rerata konsumsi BK, BO, PK, SK dan TDN (average of DM, OM, CP, CF and TDN consumtion)

\begin{tabular}{|c|c|c|c|}
\hline \multirow{2}{*}{ Variabel (variable) } & \multicolumn{3}{|c|}{ Perlakuan (treatment) } \\
\hline & $\mathrm{PO}(T 0)$ & P1 (T1) & P2 (T2) \\
\hline \multicolumn{4}{|l|}{ Konsumsi (consumption) } \\
\hline \multicolumn{4}{|l|}{$\mathrm{BK}(D M)$} \\
\hline (kg/ekor/hari) (kg/head/day) & $13.14 \pm 0.40$ & $13.68 \pm 0.91$ & $12.89 \pm 0.17$ \\
\hline$(\mathrm{g} / \mathrm{kg}$ BBM$)(g / k g B W M)^{\mathrm{ns}}$ & $136.44 \pm 0.94$ & $137.64 \pm 2.45$ & $135.52 \pm 0.34$ \\
\hline$(\% \mathrm{~kg} \mathrm{BB})(g / \mathrm{kg} \mathrm{BW})$ & $2.97 \pm 0.68$ & $2.97 \pm 0.54$ & $2.96 \pm 0.17$ \\
\hline \multicolumn{4}{|l|}{$\mathrm{BO}(O M)$} \\
\hline (kg/ekor/hari) (kg/head/day) & $10.33 \pm 0.32$ & $10.77 \pm 0.71$ & $10.15 \pm 0.14$ \\
\hline$(\mathrm{g} / \mathrm{kg} \mathrm{BBM})\left((\mathrm{g} / \mathrm{kg} B W M)^{\mathrm{ns}}\right.$ & $107.34 \pm 0.87$ & $108.35 \pm 2.02$ & $106.64 \pm 0.28$ \\
\hline \multicolumn{4}{|l|}{$\mathrm{PK}(C P)$} \\
\hline$(\mathrm{kg} / \mathrm{ekor} / \mathrm{hari})(\mathrm{kg} / \mathrm{head} /$ day $)$ & $0.94 \pm 0.03$ & $1.00 \pm 0.06$ & $0.98 \pm 0.01$ \\
\hline$(\mathrm{g} / \mathrm{kg} \mathrm{BBM})(\mathrm{g} / \mathrm{kg} B W M)$ & $9.66 \pm 0.09^{\mathrm{a}}$ & $10.08 \pm 0.18^{\mathrm{b}}$ & $10.20 \pm 0.04^{\mathrm{b}}$ \\
\hline \multicolumn{4}{|l|}{ SK $(C F)$} \\
\hline (kg/ekor/hari) ( $\mathrm{kg} / \mathrm{head} /$ day $)$ & $3.26 \pm 0.10$ & $3.44 \pm 0.22$ & $3.27 \pm 0.04$ \\
\hline$(\mathrm{g} / \mathrm{kg} \mathrm{BBM})(\mathrm{g} / \mathrm{kg} B W M)$ & $33.89 \pm 0.29^{\mathrm{a}}$ & $34.61 \pm 0.61^{\mathrm{b}}$ & $34.38 \pm 0.08^{\mathrm{ab}}$ \\
\hline \multicolumn{4}{|l|}{ TDN } \\
\hline (kg/ekor/hari) (kg/head/day) & $7.19 \pm 0.23$ & $7.85 \pm 0.21$ & $7.14 \pm 0.09$ \\
\hline$(\mathrm{g} / \mathrm{kg} \mathrm{BBM})(g / k g B W M)^{\mathrm{ns}}$ & $74.75 \pm 0.62$ & $79.02 \pm 4.95$ & $75.06 \pm 0.17$ \\
\hline \multicolumn{4}{|c|}{$\begin{array}{l}\text { Superskrip yang berbeda pada baris yang sama menunjukkan perbedaan }(\mathrm{P}<0,05)(\text { different superscript at the } \\
\text { same row indicated significant differences }(P<0.05)) . \\
\text { Non significant. }\end{array}$} \\
\hline \multirow{2}{*}{\multicolumn{4}{|c|}{$\begin{array}{l}\mathrm{BK}=\text { bahan kering }(D M=\text { dry matter }), \mathrm{PK}=\text { protein } \operatorname{kasar}(C P=\text { crude protein }), \mathrm{SK}=\text { serat } \mathrm{kasar}(C F=\text { crude } \\
\quad f i b e r), \mathrm{BO}=\text { bahan organik }(O M=\text { organic matter }), \mathrm{TDN}=\text { total digestible } \text { nutrients, } \mathrm{BB}=\text { bobot badan } \\
(B W=\text { body weight }) \text { dan } \mathrm{BBM}=\text { bobot badan metabolik }(B M W=\text { body weight metabolic }) .\end{array}$}} \\
\hline & & & \\
\hline \multicolumn{4}{|c|}{$\begin{array}{l}\mathrm{P} 0=100 \% \text { rumput }(100 \% \text { grass }), \mathrm{P} 1=25 \% \text { silase isi rumen }: 75 \% \text { rumput }(25 \% \text { rumen content silage }: 75 \% \\
\text { grass }), \mathrm{P} 2=50 \% \text { silase isi rumen }: 50 \% \text { rumput }(50 \% \text { rumen content silage }: 50 \% \text { grass }) .\end{array}$} \\
\hline
\end{tabular}

untuk menentukan fungsi dan respon ternak terhadap penggunaan pakan.

Hasil rata-rata konsumsi BK $\left(\begin{array}{lll}\% & \mathrm{BB}\end{array}\right)$ penelitian yaitu $2,96 \%$, hal ini menunjukkan bahwa konsumsi BK (\% BB) penelitian hampir sama dengan pemberian jumlah konsumsi BK yaitu 3\% BB. Pemberian BK sebanyak 3\% BB karena sapi yang digunakan adalah sapi SimPO yang merupakan silangan dengan sapi Eropa.

Konsumsi bahan organik. Hasil analisis statistik terhadap konsumsi BO $\left(\mathrm{g} / \mathrm{kg} \mathrm{BB}{ }^{0,75}\right)$ dari ketiga perlakuan menunjukkan perbedaan tidak nyata berturut-turut yaitu $\mathrm{P} 0=107,34 \pm 0,87$, $\mathrm{P} 1=108,35 \pm 2,02$, dan $\mathrm{P} 2=106,64 \pm 0,28 \mathrm{~g} / \mathrm{kg}$ $\mathrm{BB}^{0,75}$.

Perbedaan yang tidak nyata antara ketiga perlakuan terjadi karena konsumsi BK per BBM yang juga tidak berbeda nyata sehingga meng- akibatkan konsumsi BO per BBM ketiga perlakuan menjadi tidak berbeda nyata, selain itu kandungan $\mathrm{BO}$ antara rumput dan silase isi rumen yang tidak berbeda juga mempengaruhi tidak adanya perbedaan konsumsi BO per BBM ketiga perlakuan.

Perlakuan P1 dan P2 sebagian hijauan rumput diganti dengan silase isi rumen sapi tetapi karena dalam level penggantian yang relatif kecil dan kandungan BO rumput dan silase tidak berbeda, sehingga hal ini tidak berpengaruh nyata terhadap konsumsi BO pakan per $\mathrm{kg}$ BBM pada ketiga perlakuan. Konsumsi pakan $\mathrm{BO}$ sangat dipengaruhi oleh kandungan protein dan SK bahan penyusun pakan yang digunakan.

Konsumsi BO (kg/ekor/hari) penelitian yaitu $\mathrm{P} 0=10,33, \mathrm{P} 1=10,77$, dan $\mathrm{P} 2=10,15 \mathrm{~kg} /$ ekor $/$ hari hampir sama dengan hasil penelitian Endrawati et 
al. (2010) pada sapi PO dan SimPO yaitu 9,17 dan $11,74 \mathrm{~kg} / \mathrm{ekor} / \mathrm{hari}$.

Konsumsi protein kasar. Hasil analisis statistik pada Tabel 2 menunjukkan, konsumsi PK $\left(\mathrm{g} / \mathrm{kg} \mathrm{BB} \mathrm{BB}^{0,75}\right)$ dari ketiga perlakuan berturut-turut yaitu $\mathrm{P} 0=9,66 \pm 0,09, \mathrm{P} 1=10,08 \pm 0,18$ dan $\mathrm{P} 2=$ $10,20 \pm 0,04 \mathrm{~g} / \mathrm{kg} \mathrm{BB}^{0,75}$ menunjukkan perbedaan yang nyata $(\mathrm{P}<0,05)$.

Perbedaan yang terjadi antara $\mathrm{P} 1$ dan $\mathrm{P} 2$ yang diberi silase isi rumen sapi dengan P0 yang tidak diberi silase isi rumen karena pada P1 maupun P2 sebagian rumput diganti dengan silase isi rumen dimana kandungan PK silase isi rumen lebih tinggi dibanding PK rumput sehingga mengakibatkan konsumsi PK juga menjadi lebih tinggi. Ini sesuai dengan pendapat Purbowati et al. (2007) yang menyatakan bahwa faktor yang mempengaruhi konsumsi PK adalah konsumsi BK dan kandungan PK pakan.

Hasil rata-rata konsumsi $\mathrm{PK}(\mathrm{kg} / \mathrm{ekor} / \mathrm{hari})$ penelitian antara $\mathrm{P} 0, \mathrm{P} 1$, dan $\mathrm{P} 2$ berturut-turut 0,94 , 1,00, dan $0,98 \mathrm{~kg} /$ ekor/hari, sedangkan bobot badan rata-rata $\mathrm{P} 0, \mathrm{P} 1$, dan $\mathrm{P} 2$ berturut-turut 441,25, 460,34 , dan $434,75 \mathrm{~kg}$. Bila dilihat dari rata-rata bobot badan dan konsumsi PK penelitian terlihat bahwa konsumsi PK penelitian (kg/ekor/hari) hampir sama dengan pendapat Kearl (1982) yang menyebutkan bahwa sapi dengan bobot badan 450 $\mathrm{kg}$ dengan PBBH $1 \mathrm{~kg}$ maka kebutuhan PK adalah $952 \mathrm{~g} / \mathrm{ekor} / \mathrm{hari}$.

Konsumsi serat kasar. Hasil analisis statistik konsumsi $\mathrm{SK}\left(\mathrm{g} / \mathrm{kg} \mathrm{BB}^{0,75}\right)$ dari ketiga perlakuan menunjukkan perbedaan yang nyata $(\mathrm{P}<0,05)$ berturut-turut yaitu $\mathrm{P} 0=33,89 \pm 0,29, \mathrm{P} 1=$ $34,61 \pm 0,61$, dan $\mathrm{P} 2=34,38 \pm 0,08 \mathrm{~g} / \mathrm{kg} \mathrm{BB}^{0,75}$ (Tabel 2).

Perbedaan yang nyata konsumsi SK per $\mathrm{kg}$ BBM antara P0 dan P1 terjadi karena kandungan SK silase isi rumen yang lebih tinggi dibandingkan dengan kandungan SK rumput sehingga mengakibatkan konsumsi SK per kg BBM pada P1 lebih tinggi dibanding $\mathrm{P} 0$.

Apabila dilihat konsumsi SK, P2 ternyata tidak berbeda nyata dibanding P0 dan P1 walaupun P2 diberi silase isi rumen dengan porsi yang lebih banyak, hal ini dikarenakan konsumsi BK tidak berbeda, SK isi rumen lebih tinggi dan diberi isi rumen lebih banyak, maka konsumsi SK lebih tinggi. Bila dilihat dari konsumsi BK, meski tidak berbeda nyata akan tetapi secara kuantitas konsumsi BK pada P2 lebih rendah daripada P0 sehingga konsumsi SK menjadi berbeda tidak nyata.

Konsumsi total digestible nutrients. Hasil analisis statistik pada Tabel 2 menunjukkan, konsumsi TDN g/kg bobot badan metabolik (BBM) $\left(\mathrm{g} / \mathrm{kg} \mathrm{BB}{ }^{0,75}\right)$ dari ketiga perlakuan berturut-turut yaitu $\mathrm{P} 0=74,75 \pm 0,62, \mathrm{P} 1=79,02 \pm 4,95$, dan $\mathrm{P} 2=$
$75,06 \pm 0,17 \mathrm{~g} / \mathrm{kg} \mathrm{BB}^{0,75}$ menunjukkan berbeda tidak nyata. Perbedaan yang tidak nyata antara ketiga perlakuan terjadi karena konsumsi BK yang tidak berbeda nyata sehingga mengakibatkan konsumsi BO ketiga perlakuan menjadi berbeda tidak nyata.

Hasil rata-rata konsumsi TDN (kg/ekor/hari) penelitian antara $\mathrm{P} 0, \mathrm{P} 1$, dan $\mathrm{P} 2$ berturut-turut 7,19, 7,85 , dan $7,44 \mathrm{~kg} /$ ekor/hari, sedangkan bobot badan rata-rata $\mathrm{P} 0, \mathrm{P} 1$, dan $\mathrm{P} 2$ berturut-turut 441,25, 460,34, dan 434,75 kg. Dilihat dari rata-rata bobot badan dan konsumsi TDN penelitian terlihat bahwa konsumsi TDN penelitian (kg/ekor/hari) sedikit lebih tinggi dari pendapat Kearl (1982) yang menyebutkan bahwa sapi dengan bobot badan 450 $\mathrm{kg}$ dengan PBBH $1 \mathrm{~kg}$ kebutuhan TDN adalah 6,8 kg/ekor/hari. Parakkasi (1999) menyatakan bahwa tinggi rendahnya konsumsi pakan pada ternak ruminansia dipengaruhi oleh faktor lingkungan dan kondisi ternak serta faktor pakan. Menurut Pond et al. (2005), kebutuhan nutrisi pakan dipengaruhi oleh spesies dan stadium dari pertumbuhan. Penggunaan nutrisi dari pakan dipengaruhi oleh faktor spesies, umur, status fisiologi, tipe saluran pencernaan, level konsumsi pakan dan kondisi fisik pakan. Secara umum besarnya tingkat konsumsi pakan meningkat pada ternak ruminansia seiring dengan bertambahnya umur dan bobot badan.

\section{Pertambahan bobot badan harian}

Data rata-rata PBBH per ekor per hari dari ketiga perlakuan selama penelitian disajikan pada Tabel 3. Hasil analisis statistik perlakuan silase isi rumen sapi terhadap sapi potong berpengaruh tidak nyata terhadap PBBH.

Rata-rata $\mathrm{PBBH}$ antara $\mathrm{P} 0, \mathrm{P} 1$, dan $\mathrm{P} 2$ berturut-turut yaitu $0,92 \pm 0,02, \quad 0,97 \pm 0,05$, dan $0,96 \pm 0,03 \mathrm{~kg} / \mathrm{ekor} / \mathrm{hari}$. Perlakuan tidak berpengaruh terhadap PBBH. Tidak adanya perbedaan antara ketiga perlakuan terjadi karena walaupun $25 \%$ dan $50 \%$ hijauan pada $\mathrm{P} 1$ dan $\mathrm{P} 2$ diganti dengan silase isi rumen sapi tetapi jumlah rumput yang diganti sedikit sehingga penggantian silase isi rumen sapi ini tidak mempengaruhi PBBH. Hasil PBBH pada penelitian ini lebih rendah dibanding hasil penelitian yang dilakukan Yudhanto (2008) pada sapi SimPO yang mendapatkan PBBH sebesar $1,05 \mathrm{~kg} / \mathrm{ekor} / \mathrm{hari}$.

Pertambahan bobot badan harian juga dianalisis dengan menggunakan analisis kovariansi untuk mengetahui pengaruh bobot badan awal penelitian ini terhadap PBBH. Hasil analisis kovariansi PBBH dengan bobot badan awal penelitian menunjukkan bahwa $\mathrm{F}$ hitung $<\mathrm{F}$ tabel yang berarti non significant, artinya bahwa penggantian sebagian hijauan dengan silase isi rumen sapi tidak memberikan pengaruh yang nyata terhadap PBBH. 
Tabel 3. Rerata pertambahan bobot badan harian (PBBH) dan konversi pakan sapi yang diberi dengan silase isi rumen untuk substitusi rumput (average of average daily gain (ADG) and feed conversion)

\begin{tabular}{|c|c|c|c|}
\hline \multirow{2}{*}{ Variabel (variable) } & \multicolumn{3}{|c|}{ Perlakuan (treatment) } \\
\hline & $\mathrm{PO}(T 0)$ & $\mathrm{P} 1(T 1)$ & $\mathrm{P} 2(T 2)$ \\
\hline PBBH $(\mathrm{kg})(A D G(\mathrm{~kg}))^{\mathrm{ns}}$ & $0,92 \pm 0,02$ & $0,97 \pm 0,05$ & $0,96 \pm 0,03$ \\
\hline Konversi pakan (feed conversion $)^{\mathrm{ns}}$ & $14,30 \pm 0,69$ & $14,16 \pm 1,46$ & $13,45 \pm 0,70$ \\
\hline
\end{tabular}

$\mathrm{P} 0=$ rumput $100 \%$ (grass $100 \%$ ), $\mathrm{P} 1=$ silase isi rumen $75 \%$ : rumput $25 \%$ (rumen content silage $75 \%$ : grass

$25 \%$ ), $\mathrm{P} 2=$ silase isi rumen $50 \%$ : rumput $50 \%$ (rumen content silage $50 \%:$ grass $50 \%$ ).

${ }^{\mathrm{n}}$ Non significant.

Jenis pakan, konsumsi dan komposisi kimia pakan berpengaruh besar terhadap pertumbuhan, konsumsi protein dan energi yang lebih tinggi akan menghasilkan laju pertumbuhan yang cepat (Soeparno, 2005). Secara umum disebutkan bahwa faktor yang mempengaruhi pertumbuhan dan perkembangan ternak antara lain pakan, jenis kelamin, hormon, umur, lingkungan, dan iklim.

Menurut Tillman et al. (1998), pertambahan bobot badan akan terjadi apabila pakan yang dikonsumsi telah melampaui kebutuhan untuk hidup pokok. Apabila kebutuhan hidup pokok sudah terpenuhi, kelebihan nutrisi yang dikonsumsi akan ditimbun sebagai jaringan lemak dan daging (Cullison, 1979).

\section{Konversi pakan}

Hasil analisis statistik perlakuan silase isi rumen sapi terhadap konversi pakan sapi potong berpengaruh tidak nyata. Rata-rata konversi pakan antara P1, P2, dan P3 berturut-turut yaitu $14,30 \pm 0,69,14,16 \pm 1,46$, dan $13,45 \pm 0,70$. Tidak adanya perbedaan yang nyata terjadi karena konsumsi BK dan PBBH dari ketiga perlakuan tidak berbeda nyata sehingga mengakibatkan konversi pakan dari ketiga perlakuan tidak terjadi perbedaan.

Hal ini memperlihatkan bahwa penggantian sebagian rumput dengan silase isi rumen sapi sampai 50\% tidak mempengaruhi konversi pakan. Konversi pakan dipengaruhi oleh konsumsi BK dan PBBH. Pemberian silase isi rumen sapi sampai 50\% ternyata tidak memberikan hasil yang berbeda nyata terhadap konsumsi BK sehingga hal ini juga mengakibatkan konversi pakan yang juga berbeda tidak nyata.

Hasil konversi pakan pada penelitian ini sedikit lebih besar dibanding hasil penelitian Ngadiyono (1995) pada sapi Peranakan Friesian Holstein (PFH) jantan dengan konsentrat dan rumput gajah (70 : 30) menghasilkan angka konversi 10,8 dan hasil penelitian Suwignyo (2003) pada sapi Australian Commercial Cross (ACC) dengan pakan jerami padi fermentasi dan konsentrat menghasilkan konversi pakan sebesar 9,6-11,4. Konversi pakan hasil penelitian Astutik et al. (2002) pada sapi Peranakan Ongole yang diberi pakan jerami padi dan konsentrat dengan formula urea mollases (mollases 40\%) hampir sama dengan penelitian ini yakni 14,18.

Nilai konversi pakan yang semakin kecil menurut Tillman et al. (1998) berarti ternak tersebut semakin efisien dalam memanfaatkan pakan. Menurut Campbell dan Lasley (1985), konversi pakan dipengaruhi oleh kemampuan ternak dalam mencerna bahan pakan, kecukupan zat pakan untuk kebutuhan hidup pokok, pertumbuhan, dan fungsi tubuh lain serta jenis pakan yang dikonsumsi. Menurut Pond et al. (2005), nutrisi terkait langsung dengan laju pertumbuhan dan komposisi tubuh selama pertumbuhan berlangsung. Kandungan energi yang ada akan dipergunakan untuk mencukupi kebutuhan diantaranya pemeliharaan, pertumbuhan protein dan deposisi lemak.

\section{Kesimpulan dan Saran}

\section{Kesimpulan}

Dari penelitian yang telah dilaksanakan dapat disimpulkan bahwa penggantian rumput gajah dengan silase isi rumen sapi sampai dengan 50\% menghasilkan kinerja sapi potong yang sama, dengan $\mathrm{PBBH}$ yaitu $0,96 \pm 0,03 \mathrm{~kg} /$ ekor/hari dan konversi pakan $13,45 \pm 0,70$.

\section{Saran}

Perlu dilakukan penelitian lanjutan dengan mengubah perbandingan pakan antara rumput dan konsentrat yaitu persentase rumput ditingkatkan sehingga persentase penggantian rumput dengan silase isi rumen sapi juga akan lebih banyak, dan meningkatkan persentase pemberian silase isi rumen sapi sampai $100 \%$.

\section{Daftar Pustaka}

Arora, S.P. 1989. Pencernaan Mikroba pada Ruminansia. Gadjah Mada University Press. Yogyakarta.

Astutik, S.I., M. Arifin, dan W.S. Dilaga. 2002. Respon produksi sapi Peranakan Ongole berbasis pakan jerami padi terhadap formula urea molasse block. Prosiding Seminar 
Nasional Teknologi Peternakan dan Veteriner. Pusat Penelitian dan Pengembangan Peternakan. Departemen Pertanian, Bogor. Hal: 82-85.

Campbell, J.R. and J.F. Lasley. 1985. The Science of Animal Serve Humanity. $2^{\text {nd }}$ Ed., Tata McGraw-Hill Publishing Co. Ltd., New Delhi.

Christensen, R. 1996. Analysis of Variance, Design and Regression: Applied Statistic Methods. Chapman and Hall. London.

Cullison, A.E. 1979. Feed and Feeding. $2^{\text {nd }}$ Ed. Reston Publishing Company Inc. A Prentice Hill Company. Reston Virginia.

Endrawati, E., E. Baliarti, dan S.P.S. Budhi. 2010. Performans induk sapi silangan SimmentalPeranakan Ongole dan induk sapi Peranakan Ongole dengan pakan hijauan dan konsentrat. Buletin Peternakan 34(2): 86-93.

Kearl, L.C. 1982. Nutrient Requirement of Ruminant in Developing Countries. International Feedstuff Institute, Utah Agriculture Experiment Station. Utah State University, Logan. Utah.

Messersmith, T.L. 1973. Evalution of Dried Paunch Feed as Roughages Source in Ruminant Finishing Ration. M.A. Departement of Animal Science. University of Nebraska, Lincoln.

Ngadiyono, N. 1995. Pertumbuhan serta sifat-sifat karkas dan daging sapi Sumba Ongole, Brahman Cross dan Australian Commercial Cross yang dipelihara secara intensif pada berbagai bobot potong. Disertasi. Institut Pertanian Bogor, Bogor.

Parakkasi, A. 1999. Ilmu Nutrisi dan Makanan Ternak Ruminan. Penerbit Universitas Indonesia, Jakarta.

Purbowati, E., C.I. Sutrisno, E. Baliarti, S.P.S. Budhi, dan W. Lestariana. 2007. Pengaruh pakan komplit dengan kadar protein dan energi yang berbeda pada penggemukan domba lokal jantan secara feedlot terhadap konversi pakan. Prosiding Seminar Nasional Teknologi Peternakan dan Veteriner. Pusat Penelitian dan Pengembangan Peternakan,
Badan Penelitian dan Pengembangan Pertanian, Departemen Pertanian, Bogor. Hal: 394-401.

Pond, W.G., D.C. Church, K.R. Pond and P.A. Schoknecht. 2005. Basic Animal Nutrition and Feeding. John Wille and Sons, Inc. New York, USA.

Soeparno. 2005. Ilmu dan Teknologi Daging. Cetakan keempat. Gadjah Mada University Press. Yogyakarta.

Suwignyo, B. 2003. Penggunaan complete feed berbasis jerami padi fermentasi pada sapi Australian Commercial Cross terhadap konsumsi nutrien, pertambahan bobot badan dan kualitas karkas. Tesis. Pascasarjana. Universitas Gadjah Mada. Yogyakarta.

Tillman, A.D., H. Hartadi, S. Reksohadiprodjo, S. Prawirokusumo, dan S. Lebdosoekojo. 1998. Ilmu Makanan Ternak Dasar. Cetakan keenam. Gadjah Mada University Press. Yogyakarta.

Utomo, R. 2001. Penggunaan jerami padi sebagai pakan basal : suplementasi sumber energi dan protein terhadap transit partikel pakan, sintesis protein mikroba, kecernaan dan kinerja sapi potong. Disertasi. Program Pascasarjana. Universitas Gadjah Mada. Yogyakarta.

Utomo, R., L.M. Yusiati, U. Umiyasih, Aryogi, dan Isnandar. 2007. Pemanfaatan Isi Rumen Limbah Rumah Potong Hewan Sebagai Pakan Alternatif Pengganti Hijauan. Kerjasama UGM Yogyakarta dengan Badan Penelitian dan Pengembangan Pertanian Jakarta. Laporan Penelitian KKP3T Deptan.

Van Soest, P.J. 1994. Nutritional Ecology of Ruminant, $2^{\text {nd }}$ ed. Comstock Publishing. Associates Advisum, of Cornell University Press, Ithaca, London.

Yudhanto, H. 2008. Performan dan hubungan antara berat badan dengan ukuran tubuh sapi Peranakan Ongole dan Simmental-PO jantan pada pemeliharaan secara feedlot. Skripsi Sarjana Peternakan. Fakultas Peternakan. Universitas Gadjah Mada. Yogyakarta. 